\title{
Democracy, Dictatorship, and Adolescent Self-Esteem: A Cross-Sectional Comparison Across the Iron Curtain
}

\author{
Carl Antonson ${ }^{1}$, Frida Thorsén ${ }^{1}$, Rada Berg ${ }^{1}$, Karolina Palmér $^{1}$, Jan Sundquist ${ }^{1} \&$ Kristina Sundquist ${ }^{1}$ \\ ${ }^{1}$ Center for Primary Health Care Research, Lund University / Region Skåne, Sweden \\ Correspondence: Carl Antonson, Center for Primary Health Care Research, Clinical Research Centre (CRC), \\ Building 28, Floor 11, Jan Waldenströms gata 35, Skåne University Hospital, SE-205 02 MALMÖ, Sweden. Tel: \\ 46-(0)708-483472. E-mail: carl.antonson@med.lu.se
}

Received: May 20, 2019 Accepted: July 22, 2019 Online Published: July 29, 2019

doi:10.5539/jedp.v9n2p45 URL: http://doi.org/10.5539/jedp.v9n2p45

\begin{abstract}
Background: Democracy and dictatorship are opposite forms of governance and may influence children differently, partly through the school curriculum.

Methods: Data were collected in the communistic dictatorship of Bulgaria before the fall of the Berlin wall and in the West-European democracy of Sweden. The aims were to compare self-esteem between Swedish and Bulgarian adolescents, examine sex differences and investigate potential interactions between country and sex. We used the well-validated self-reporting questionnaire 'I Think I Am' scale (ITIA) measuring self-esteem.
\end{abstract}

Results: A total of 100 Swedish (58 boys, 42 girls) and 88 Bulgarian (41 boys, 47 girls) were included in the analyses. The Swedish male adolescents reported a significantly higher global self-esteem than the Bulgarian males. No country difference in global self-esteem was found between the females. For the two relational sub-scales 'Relations with the family' and 'Relations with others' there were significant differences between the two countries where the Swedish adolescents of both sexes had significantly higher scores. The Bulgarian adolescents had fewer sex differences than the Swedish ones.

Conclusions: Our study is based on the only known existing data from before the fall of the Berlin wall comparing self-esteem in a country belonging to the autocratic Soviet-bloc and a West-European democracy, data that are no longer possible to obtain. The observed differences between countries and sexes may be explained by the differences in governance. Sweden formed adolescents with significantly higher self-esteem than Bulgaria, which might have been caused by social stressors leading to a 'Dictatorship damage' consisting of a lower self-esteem. The lower difference in self-esteem between the sexes in Bulgaria could possibly be attributed to the idealization of the strong emancipated woman, which was a social icon in the Soviet-bloc.

Trial Registration: The trial was registered in the local ethics committee.

Keywords: adolescent self-esteem, cross-sectional, democracy, dictatorship

\section{Background}

\subsection{Democracies and Dictatorships in Europe}

At the Yalta-Conference in February 1945, Stalin, Roosevelt and Churchill divided the continent in terms of interest-spheres in order to reorganize post-war Europe. As Churchill pointed out in his famous 'The Sinews of Peace'-speech in early 1946 the political changes in Europe during and after the Second World War were immense: 'From Stettin in the Baltic to Trieste in the Adriatic, an iron curtain has descended across the Continent. Behind that line lie all the capitals of the ancient states of Central and Eastern Europe. Warsaw, Berlin, Prague, Vienna, Budapest, Belgrade, Bucharest and Sofia, all these famous cities and the populations around them lie in what I must call the Soviet sphere, and all are subject in one form or another, not only to Soviet influence but to a very high and, in many cases, increasing measure of control from Moscow' (Churchill, 1946).

This division of Europe meant that Bulgaria, one of the two countries included in the present study, came under Soviet influence and became the communistic dictatorship known as the People's Republic of Bulgaria. By contrast, Sweden, the other country included in this study, was neutral during the Second World War and 
remained neutral after the war. Sweden had, however, a clear leaning towards the democracies of Europe and the U.S. and represented a parliamentary democracy on the other side of the Iron Curtain.

\subsection{Democracy and Autocracy/Dictatorship}

A simple, clear-cut definition of democracy has still not been proposed and there is reportedly a fine line between and a too narrow definition being to exclusive and a too general definition being too inclusive. A too vague definition may lead to conceptual stretching to the point of being useless (Collier \& Levitsky, 1997; Storm, 2008). One explanation for this is that there has been a tendency to concentrate too much on the exact legal and institutional aspects (Kimber, 1989) and that other aspects are of importance. An approach for addressing the problem of avoiding conceptual stretching, given a definition which too often is found to be too idealistic and at the same time providing a high degree of differentiation, is to add a describing adjective to democracy further specifying the underlying benchmarks of a regime (Collier \& Levitsky, 1997; Storm, 2008). Collier and Levitsky's model on generality (Collier \& Levitsky, 1997) is reported to be the most researched model on such underlying conceptual benchmarks (Storm, 2008). A democracy is a regime type, just like the totalitarianism of the communistic dictatorship, specifying the underlying general principles rather than any detailed institutional practices (Kimber, 1989). Research based on general principles of democracy has been reported to be focusing on generating knowledge rather than simply categorizing regimes and reduces the need of constructing diminished subtypes (Storm, 2008).

According to Kimber a regime is the set of rules, norms, and conventions that govern the operation of the political process. The three fundamental principles in democracy are: 1.) The authority structure is an 'upward control' where the ultimate sovereignty lies at the lowest of the authority structure, 2.) The value of political equality, and 3.) The individuals' norm-governed behaviour where individual and institutional behaviour is limited in accordance with the two previous principles institutionalised through law but also at a level of meta-rule as in breaking laws that produces anti-democratic results. Built on these principles, democracy can be defined as a 'type of regime in which the demos, as defined, exercises control over collective decisions in the sense that a given set of freely expressed individual preferences, together with a given mechanism for producing a collective decision from them, entail the outcome, which is then applied, where relevant, to all members of the demos' (Kimber, 1989).

Democracy and autocracy (dictatorship) are forms of government that could either be seen as a diametrically opposed dichotomy or the opposite poles on a continuum where nations can move in either direction (Storm, 2008). One definition of an authoritarian regime is one that completely lack the three core values of democracy, which Collier and Levitsky as well as Storm defines as having: 1.) Reasonably competitive elections, devoid of massive fraud with broad suffrage, 2.) Basic civil liberties: freedom of speech, assembly, and association, and 3.) Elected governments that have effective power to govern (Collier \& Levitsky, 1997; Storm, 2008). A fourth additional core value is the vaguely defined 'additional political, economic, and social features associated with industrial democracy'. Storm moves away from Collier and Levitsky's model in that she abstains from having an internal order of the core values but rather sees them as building blocks that could be combined in different combinations, each giving an extra dimension to democracy (Storm, 2008).

Another definition of dictatorship from the psychological literature, rather than the political, can be defined as a governance where the country is ruled by a single leader or a clique, where the vast majority of the people has no voice and the mechanism of control is thus brute force rather than identity and emotional attachment (Moghaddam, 2013). A democracy, on the other hand, can be defined as a country where a citizen can speak out freely without fear of retribution from the society, where the leaders can be voted out from office by the citizens in fair elections, where minorities are protected, and where the courts are independent of the government (Moghaddam, 2013).

\subsection{Socialization}

The society forms its compatriots as the compatriots form the society, and amongst those children are the most plastic. Thus, two different societies, with different governance, may form different citizens. And as humans are social beings and can only be understood in a social context, one has to look upon society in order to grasp a whole picture of an individual (E. Aronson \& J. Aronson, 2012). In the same way that a new-born baby arrives to a social context, a society will form citizens of a certain psychological profile (Moghaddam, 2013).

One of the ways the government controls the development of the nation's children is through the educational system and the school curriculum. Socialization of the young is also conducted in order to form the people to view the party and/or the supreme dictator as something sacred (Moghaddam, 2013). Education in a Soviet-bloc 
dictatorship was seen both as a crucial step in both forming a 'new revolutionary personality' as well as the emancipation of women and, at a later stage, giving the prospective parents the possibility to educate their offspring in a socialistic manner (Kalling-Kant, 1948; Kharkordin, 1999; Makarenko, 1979; Molyneux, 1981).

\subsection{Soviet-Bloc Pedagogics}

'The design of a person as a product of education should be made according to the order of the society.' represents a famous quote by the main pedagogical theorist and teacher in the Soviet-bloc countries, Anton Makarenko (1888-1939) (Kharkordin, 1999). He has even been described as 'canonized' by the Soviet-bloc authorities (Bronfenbrenner, 1976). His theories were based on Marxism-Leninism and were formed through organizing institutions for child delinquents, which were orphaned during the tumultuous years surrounding the Russian revolution (Makarenko, 1979). Kalling-Kant describes that the Bolshevik ideology, on which the Soviet educational system was built, gives a number of characteristics into which the educational system normatively should form the children: anti-religiousness, suspiciousness towards non-socialistic values, class-consciousness and hardness towards strong emotions, non-proletarianism and infidelity towards the system. This brings a striving for a better future through high demands on production as a result of work and the idealization of work (Kalling-Kant, 1948).

The communistic way of education was not to educate individuals but to form a group with a socially accepted common goal; a kollektiv (Kharkordin, 1999). Makarenko saw education in a materialistic way with the main outcome of pedagogical theory being to form the individual in an industrial-like fashion into a part of the kollektiv thus creating a good communist, as the meaning of someone's life was the duty towards the kollektiv. This model was used in other socialistic states, i.e. Bulgaria (Socialist Party of Bulgaria, 1987) and Vietnam (Kharkordin, 1999). Makarenko describes how the worship of work and the overall societal goal of production should be met through 'polytechnic education' with workshops, handicraft and factory work as a marriage between school education and industry (Kalling-Kant, 1948; Makarenko, 1979). According to Kalling-Kant (Kalling-Kant, 1948) and Kharkordin (Kharkordin, 1999), the most important ingredients in Makarenko's pedagogical theories were the following: a militaristic based discipline where the individual's needs were irrelevant; anti-religiousness; the development of a conspicuous mental hardness and a contempt of weakness in order to be able to fight the ever-present enemies of communism; an ever-present competition between groups at all levels of the hierarchy to achieve more and better; and to fight 'false' kollektivs, defined as groups not oriented towards the production.

The goals were met mainly through punishment of any member in the kollektiv who did not adhere to the norm or achieve well enough within the group itself but also rewards, which made the group shame those that did not deserve the reward. According to Bronfenbrenner, the children themselves exerted the power of punishment in the form of comrades' courts (Bronfenbrenner, 1962) and sentenced punishments, both corporal and psychological, through shaming and ostracizing the delinquent (Kharkordin, 1999). This is also well-described in Makarenko's own work (Kalling-Kant, 1948; Makarenko, 1979). The pedagogics in Bulgaria was mainly built on the Soviet model and Makarenko's theories (Socialist Party of Bulgaria, 1987). Todor Zhivkov, the leader of the Socialist Party of Bulgaria for decades, said that the most important goal for the raising of the children is Marxist self-discipline and self-control from an early age, as this should be the most characteristic feature of the socialist personality type. Societal norms established by the government should be followed without questioning. Social control was mentioned as being both formal but also informal (Socialist Party of Bulgaria, 1987) through the mutual surveillance where all interpersonal relations should have the party's goals as their supreme goal (Kharkordin, 1999).

\subsection{Swedish Pedagogics}

In Sweden, the compulsory school's main goal, as stated in the National curriculum in 1980 (Läroplan för grundskolan 1980) (Skolöverstyrelsen, 1980), with respect to politics, was to remain neutral in all aspects apart from democratic values and respect for human rights, which was to be imposed in all pupils as an intrinsic good. The National curriculum also states that the school is to cooperate with the family on all subjects concerning both school and children although the family has the overall responsibility for the rearing of the child. All children should have the equal right to education and the National curriculum also stresses the value of work and handicraft. For example, up to ten weeks should be spent outside the school in a workplace, i.e. in an office, a workshop or an industry; suggestions which actually are well in line with Makarenko's Polytechnique ideal (Makarenko, 1979). The Swedish school should also strive to let the children express their individualism and personal integrity, to strive for gender equality and to take an extra responsibility for minorities and those with extra needs. The Swedish pupil should also be educated to oppose oppression and to help others in need. This 
should be done by educating and encouraging the children to be free and independent citizens, partly by rationally analysing topics and ethical values that could be a matter of conflict, although with the exception of democratic ideals where the school should be adamantly pro-democratic. Conflicts should be solved via peaceful means and ethical discussions. Journalism without interference and censorship of free speech is also applied as a work method of shaping the democratic child. Critical analysis and empiricism are also put forward as important methods both in groups and individually, where individualisation is encouraged together with understanding of the importance of cooperation. The curriculum also states that the pupils, through collective work, should oppose tendencies towards bullying and xenophobia.

The National Swedish curriculum also points out the personality characteristic self-esteem as one important personality trait in students that could be increased through cooperation (Skolöverstyrelsen, 1980). Self-esteem is often defined as a personality characteristic that mirrors the level of global regard that one has for oneself as a person (Harter, 1993; Kling, Hyde, Showers, \& Buswell, 1999). It is widely recognised that self-esteem is closely related to psychopathology in adolescents, particularly internalising types where low levels of self-esteem are correlated with a higher degree of depression, anxiety and eating- and disrupting disorders (Birgerstam, 2013; Bos, Huijding, Muris, Vogel, \& Biesheuvel, 2010; Kling et al., 1999). Global self-esteem was also shown to be well correlated with neuroticism (negatively) and extraversion (positively) in a cross-cultural study conducted in 53 different countries (Schmitt \& Allik, 2005).

\subsection{Self-Esteem}

Global self-esteem is often lower in females than males and this difference is particularly high in late adolescence (Birgerstam, 2013; Kling et al., 1999). Several hypotheses have been proposed in an attempt to explain this difference; gender roles where masculinity scores are positively correlated to self-esteem, gender stereotypes in peer interaction, interaction with teachers, cultural emphasis on female physical appearance, violence against women and differing athletic participation between sexes in adolescence. Furthermore, the body maturation during puberty differs between the sexes; this difference may lead to lower self-esteem in the girls as the boys who generally want to become stronger gain muscle mass and girls who generally want to become thinner gain body fat (Kling et al., 1999). It is possible that a communistic society puts a lesser emphasis than capitalistic societies on girls' and young women's physical appearance and that this potential difference between societies can have a positive effect on girls' and young women's self-esteem in communistic countries.

To the best of our knowledge, no comparative studies of different aspects of self-esteem among adolescents from the Soviet-bloc and adolescents from the democracies of Western Europe exist. The present study is part of a cross-cultural project that started before the fall of the Berlin wall in 1989 with the overall aim to study personality development in adolescents in Sweden and Bulgaria, two countries on each side of the Iron curtain. The specific aims in this study were to: compare self-esteem between Swedish and Bulgarian adolescents; examine sex differences; and investigate potential interactions between country and sex; i.e. whether country modifies the potential sex differences. No hypotheses were pre-registered as such procedures were not applied at the time of the data collection.

\section{Methods}

\subsection{Study Population}

One country on each side of the Iron curtain, Sweden and Bulgaria, was included in the present study. At the time of the data collection Bulgaria (the People's Republic of Bulgaria) was a communistic dictatorship, and Sweden was a parliamentary constitutional monarchy. One way of quantifying democracy and autocracy (dictatorship) is through the Polity IV Index with an 11-point scale on democracy and an 11-point scale on autocracy that is combined into a 21-point Polity score based on Eckstein and Gurr's research in the 1970's and elaborated by Marshall (Marshall, Gurr, \& Jaggers, 2018). This index is currently one of the most widely used indexes measuring democracy/autocracy (Hogstrom, 2013) and reports governance characteristics from the year 1800 for purposes of global comparative analyses (Marshall et al., 2018). The democracy score in 1989, i.e. the year when the Berlin wall fell, was 10 (Full Democracy) in Sweden and -7 (Autocracy) in Bulgaria according to the Polity IV index (range: -10 to +10 ) (Marshall et al., 2018). The scores of the subdivided Polity IV-scale shows that Sweden had a regulated chief executive recruitment (level 3) with a competitive election (level 3), whereas Bulgaria had a designational (level 2) ditto chosen without formal competition by the communistic party (level 1). Both countries had a theoretical open recruitment of the chief executives (level 3). The level of executive constraints, or decision rules, differed largely with Sweden scoring on the level of executive parity (level 7) or subordination whereas Bulgaria only had a slight to moderate limitation on executive authority (level 3). The level of Regulation of participation was regulated (level 5) in Sweden and only sectarian (level 3) in 
Bulgaria. The largest difference was seen in competitiveness of participation where Sweden had a competitive (level 5) and Bulgaria had a repressed competitiveness (Marshall et al., 2018). Despite these differences between the two countries, they are similar in several other aspects, i.e. both countries are located in Europe, have a Christian religion and a language that is almost exclusively spoken within the country and are relatively secular. The primary school completion rate in 1990 was $99.5 \%$ in Bulgaria and $96.5 \%$ in Sweden (The World Bank, 2016). The populations of Bulgaria and Sweden in 1990 were also comparable in size: 8.821 and 8.559 million inhabitants, respectively (United Nations Secretariat, 2012). During the time of the data collection, both countries were known for their industrial high-technological competence with Bulgaria producing a large percentage of the electronics in the Soviet-bloc and Sweden having several high-technological companies, such as Ericsson and ABB that were considered leaders in their fields.

The present study was based on data collected from questionnaires and filled in by the pupils in their classrooms under the supervision of the third author a specialist in child and adolescent psychiatry, a licensed physician in both Bulgaria and Sweden.

The study population consisted of 203 adolescents in total, 111 from Sweden and 92 from Bulgaria. Data were collected in the autumn terms 1988 and 1989 in Bulgaria, before the fall of the Berlin wall on November $9^{\text {th }} 1989$, and in Sweden during the spring terms 1989 and 1991. The questionnaires in Sweden were collected in the $9^{\text {th }}$ grade when the adolescents were aged 15 to 16 years. In Bulgaria, the data were collected in the $10^{\text {th }}$ grade. The Swedish $9^{\text {th }}$ grade was comparable to the Bulgarian $10^{\text {th }}$ grade in terms of age as the Bulgarian students started school one year earlier than their Swedish counterparts.

The Bulgarian schools represented a broad sample of schools in Sofia organized within the Practical Technical Centre, an educational centre for all upper secondary school students in Sofia where the students were taught additional technical skills and handicrafts. According to Professor Atchkova from the Children and Adolescent Psychiatric Clinic, Medical Academy, Sofia, the study population was deemed representative in sociodemographic terms for the Bulgarian society at the time. The two Swedish schools were situated in Västerås, a middle-sized city with a population of around 120000 individuals in 1990. The schools were chosen from different areas of the city in order to obtain a representative study sample.

The questionnaires were collected in an unidentified manner. Exclusion criteria were inability to read and write the national language and being a resident in the country for less than five years. In both countries, there were no students that were unable to read and write the national language and very few students were excluded due to recent immigration (both countries had a small proportion of immigrants during the time of the data collection). The Swedish participation rate varied slightly between classes (range 63-79\%) and of 155 Swedish students, 111 participated (72\%). Reasons for non-response were refusal from the parents to participate, illness, absenteeism or fulfilling some of the exclusion criteria mentioned above.

In Bulgaria, the non-response rate was unknown, but no flu epidemic was reported during the data collection. Non-response was therefore deemed to be low in Bulgaria.

\subsection{The Psychometric Questionnaire 'I Think I Am'}

The 'I Think I Am' scale (ITIA) is a self-reporting questionnaire measuring self-esteem with the original name in Swedish "Jag Tycker Jag Är". The ITIA was developed by the Swedish psychologist Pirjo Birgerstam in 1981 and is validated for the age group 9-18 (Birgerstam, 2013). We used the MH-version of the scale, which was developed for the age group in our study population (Ouvinen-Birgerstam, 1985). The ITIA global scale is a four-level, 72-item, Likert questionnaire (score for each item -2 to +2 , without zero) divided into five sub-scales that includes items that previously have been shown to be central for self-esteem: "Physical characteristics", "Talents and skills", "Psychological well-being", "Relations with the family", and "Relations with others". The questionnaire consists of both positive (i.e. "I have often good ideas") and negative (i.e. "I don't like my body") items randomly ordered in order to avoid negative item bias in intercultural studies (Schmitt \& Allik, 2005). A high score reflects a positive self-esteem and a low score reflects a negative self-esteem.

The reliability of the global scale has been analysed with Cronbach's alpha with $\alpha=0.91$ to 0.93 on the ITIA-total (Birgerstam, 2013). According to Birgerstam, the sub-scales and individual items in the scale also have a good reliability. Test-retests results show good reliability over time (Birgerstam, 2013).

The validity of the scale is high and was initially analysed through correlation tests between psychological interviews with children where the interviewer was blinded to the result of the questionnaire and also made a thorough clinical psychological assessment of the children's self-esteem, which then was compared to the results of the questionnaire showing a high correlation. A high correlation was also found between interviews with the 
schoolteachers and the ITIA-scale (Ouvinen-Birgerstam, 1984). A low score on the ITIA has been shown to be significantly correlated with a range of negative psychological traits as well as with psychiatric and somatic disabilities (Birgerstam, 2013). Furthermore, the ITIA-scale has been evaluated with respect to correlation to other psychometric scales such as Becks Depression Inventory, Beck's Anxiety Inventory, and Beck's Youth Inventories (Birgerstam, 2013) The ITIA-scale has previously been used to investigate differences in self-esteem between cultures, i.e. between different immigrant groups in Sweden and ethnic Swedes (Ouvinen-Birgerstam, 1984). The scale has also been used in a study from Mexico City where children from ordinary schools were compared with children from orphanages and those living on the streets (Arvidsson, 1998). The questionnaire is the second most used scale in terms of number of clinics using it in child and adolescent psychiatry assessments in the Stockholm County Council (Greater Stockholm area)(Dunerfeldt, 2010).

The bilingual third author, whose mother tongue is Bulgarian, made the translation of the questionnaire from Swedish into Bulgarian in 1988. Prof. Atchkova from the clinic of Children and Adolescent Psychiatry, Medical Academy, Sofia, aided in honing the fine nuances of the Bulgarian language used in the translation. The Bulgarian translation was then re-translated back to Swedish by two bilingual physicians and the two translations were compared by the third author and deemed to have a good validity.

\subsection{Statistical Analysis}

All analyses were repeated for the total score (ITIA-scale global) and for the five sub-scales. The number of individuals and sex distribution are presented as numbers and percentages and the scores are presented as means and SDs, stratified by country (Table 1).

To examine our primary aim, self-esteem in adolescents and differences between Sweden and Bulgaria, we used linear regression models; the first model was univariate and the second was adjusted for sex (Table 2).

We also examined whether there were any interactions between country and sex, i.e. whether the possible country differences in self-esteem differed by sex as well as whether the possible sex differences in self-esteem differed by country. To examine this, we used linear regression models with an interaction term between country and sex (Table 3). Interactions tests are highly useful for the examination of whether a certain variable modifies the potential effect of another variable (i.e., effect modification).

Participants who had not responded to three or more items on the scales were counted as missing. In a sensitivity analysis, the mean number of points for the questions the students had responded to was used to impute values for the missing questions. We also examined whether influential observations and outliers affected our results (Supporting information in Appendix A).

We used a significance level of $\mathrm{p}<0.05$. STATA version 14 (Stata Corp LP) was used for all statistical analyses.

\section{Results}

111 adolescents ( 65 boys and 46 girls) from Sweden and 92 adolescents ( 44 boys and 48 girls) from Bulgaria were included in the study. Of those adolescents, 100 Swedish ( 58 boys and 42 girls) and 88 Bulgarian (41 boys and 47 girls) were included in the analyses; ten Swedish and four Bulgarian adolescents were excluded, as described in the manual, due to more than two missing items (Birgerstam, 2013). One Swedish adolescent was excluded due to being an extreme outlier that was deemed to influence the results too much. Appendix A shows boxplots of the global ITIA-scale (where the outlier from the Swedish study population is shown).

Table 1 shows the descriptive data on the participants in the study, divided by country and sex, with means and standard deviations on the ITIA global-scale and the five sub-scales.

Table 1. Descriptive data on participants and the 'I think I Am'-scale (ITIA) and its sub-scales divided by country and sex.

\begin{tabular}{lll}
\hline & Sweden & Bulgaria \\
\hline Included in the study, number (\%) & & \\
All & 111 & 92 \\
Boys & $65(58.6)$ & $44(47.8)$ \\
Girls & $46(41.4)$ & $48(52.2)$ \\
\hline
\end{tabular}




\begin{tabular}{|c|c|c|}
\hline \multicolumn{3}{|c|}{ Included in the analysis ${ }^{\mathrm{a}}$, number $(\%)$} \\
\hline All & 100 & 88 \\
\hline Boys & $58(58.0)$ & $41(46.6)$ \\
\hline Girls & $42(42.0)$ & $47(53.4)$ \\
\hline \multicolumn{3}{|c|}{ ITIA-scale global, mean (SD) } \\
\hline All & $57.4(27.8)$ & $47.5(23.6)$ \\
\hline Boys & $62.2(29.2)$ & $49.4(23.3)$ \\
\hline Girls & $50.8(24.0)$ & $45.8(24.0)$ \\
\hline \multicolumn{3}{|c|}{ Physical characteristics, mean (SD) } \\
\hline All & $11.4(8.2)$ & $11.5(6.5)$ \\
\hline Boys & $13.3(8.3)$ & $13.0(6.4)$ \\
\hline Girls & $8.6(7.4)$ & $10.2(6.3)$ \\
\hline \multicolumn{3}{|c|}{ Talents and skills, mean (SD) } \\
\hline All & $9.0(8.9)$ & $8.5(6.7)$ \\
\hline Boys & $10.4(8.1)$ & $7.2(7.2)$ \\
\hline Girls & $7.0(9.7)$ & $9.6(6.2)$ \\
\hline \multicolumn{3}{|c|}{ Psychological well-being, mean (SD) } \\
\hline All & $12.2(8.2)$ & $10.1(9.2)$ \\
\hline Boys & $14.2(8.4)$ & $12.8(8.3)$ \\
\hline Girls & $9.4(7.1)$ & $7.7(9.4)$ \\
\hline \multicolumn{3}{|c|}{ Relations with the family, mean (SD) } \\
\hline All & $13.8(8.4)$ & $10.1(7.3)$ \\
\hline Boys & $13.1(9.0)$ & $9.6(6.8)$ \\
\hline Girls & $14.8(7.5)$ & $10.6(7.8)$ \\
\hline \multicolumn{3}{|c|}{ Relations with others, mean (SD) } \\
\hline All & $11.1(6.9)$ & $7.3(7.8)$ \\
\hline Boys & $11.2(7.4)$ & $6.7(7.6)$ \\
\hline Girls & $10.9(6.2)$ & $7.8(7.9)$ \\
\hline
\end{tabular}

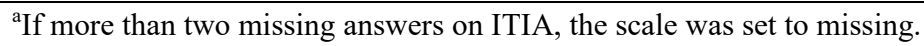

Table 2 shows the estimated mean differences between the Swedish and Bulgarian adolescents. Since there was a different proportion of boys and girls between the countries, and the norm data shows differences between the sexes (Birgerstam, 2013), the results were sex-adjusted in the linear regression model. Swedish adolescents had a nine points higher mean than the Bulgarians on the ITIA global-scale $(p=0.02)$, after adjusting for sex, indicating that the Swedes had a higher global self-esteem. There were no significant differences between the two countries in the sub-scales 'Physical characteristics', 'Talents and skills', and 'Psychological well-being'. The two sub-scales measuring relational self-esteem, i.e., 'Relations with the family' and 'Relations with others', both showed a 3.8 points higher score in the Swedish adolescents ( $p=0.001$ and $p=0.0005$, respectively), after adjusting for sex. 
Table 2. Estimated mean differences $(\beta)$ between the Swedish and Bulgarian adolescents in the global 'I think I Am'-scale (ITIA) and its sub-scales using linear regression models, unadjusted and adjusted for sex.

\begin{tabular}{|c|c|c|c|c|c|c|}
\hline & \multicolumn{6}{|c|}{ Sweden - Bulgaria } \\
\hline & \multicolumn{3}{|c|}{ Unadjusted } & \multicolumn{3}{|c|}{ Adjusted for sex } \\
\hline & $\beta^{\mathrm{a}}$ & $\mathrm{p}$ & $95 \% \mathrm{CI}$ & $\beta^{\mathrm{a}}$ & $\mathrm{p}$ & $95 \% \mathrm{CI}$ \\
\hline ITIA-scale global & 9.9 & 0.009 & $2.5 ; 17.4$ & 9.0 & 0.02 & $1.6 ; 16.5$ \\
\hline Physical characteristics & -0.2 & 0.87 & $-2.3 ; 2.0$ & -0.6 & 0.57 & $-2.7 ; 1.5$ \\
\hline Talent and skills & 0.5 & 0.68 & $-1.8 ; 2.8$ & 0.4 & 0.73 & $-1.9 ; 2.7$ \\
\hline Psychological well-being & 2.1 & 0.09 & $-0.4 ; 4.6$ & 1.6 & 0.20 & $-0.9 ; 4.0$ \\
\hline Relations with the family & 3.7 & 0.002 & $1.4 ; 6.0$ & 3.8 & 0.001 & $1.5 ; 6.1$ \\
\hline Relations with others & 3.8 & 0.0005 & $1.7 ; 5.9$ & 3.8 & 0.0005 & $1.7 ; 6.0$ \\
\hline
\end{tabular}

${ }^{\mathrm{a}} \beta$ denotes difference in score between Swedish and Bulgarian adolescents.

Table 3 shows the estimated mean differences between the countries and sexes. The country differences are shown separately by sex and the sex differences are shown separately by country. Tests of interactions between country and sex are also shown.

Table 3. Estimated mean differences ( $\beta$ ) between countries and sexes in 'I think I Am'-scale (ITIA) and its sub-scales using linear regression models with an interaction between country and sex

\begin{tabular}{|c|c|c|c|c|c|c|c|}
\hline & \multicolumn{3}{|c|}{ Sweden - Bulgaria } & \multicolumn{3}{|c|}{ Boys - Girls } & \multirow{2}{*}{$\begin{array}{c}\begin{array}{c}\text { Test of interaction } \\
\text { between country and sex }\end{array} \\
p\end{array}$} \\
\hline & $\beta^{\mathrm{a}}$ & $\mathrm{p}$ & $95 \% \mathrm{CI}$ & $\beta^{\mathrm{b}}$ & $\mathrm{p}$ & $95 \% \mathrm{CI}$ & \\
\hline ITIA-scale global & & & & & & & 0.31 \\
\hline Boys & 12.7 & 0.02 & $2.4 ; 23.0$ & & & & \\
\hline Girls & 5.0 & 0.36 & $-5.7 ; 15.7$ & & & & \\
\hline Sweden & & & & 11.3 & 0.03 & $1.1 ; 21.6$ & \\
\hline Bulgaria & & & & 3.6 & 0.51 & $-7.2 ; 14.4$ & \\
\hline Physical characteristics & & & & & & & 0.40 \\
\hline Boys & 0.3 & 0.86 & $-2.7 ; 3.2$ & & & & \\
\hline Girls & -1.5 & 0.32 & $-4.6 ; 1.5$ & & & & \\
\hline Sweden & & & & 4.7 & 0.002 & $1.8 ; 7.6$ & \\
\hline Bulgaria & & & & 2.9 & 0.07 & $-0.2 ; 5.9$ & \\
\hline Talents and skills & & & & & & & 0.02 \\
\hline Boys & 3.1 & 0.053 & $-0.04 ; 6.3$ & & & & \\
\hline Girls & -2.6 & 0.13 & $-5.9 ; 0.8$ & & & & \\
\hline Sweden & & & & 3.4 & 0.04 & $0.2 ; 6.5$ & \\
\hline Bulgaria & & & & -2.3 & 0.17 & $-5.6 ; 1.0$ & \\
\hline Psychological well-being & & & & & & & 0.87 \\
\hline Boys & 1.4 & 0.42 & $-2.0 ; 4.7$ & & & & \\
\hline Girls & 1.8 & 0.32 & $-1.7 ; 5.3$ & & & & \\
\hline Sweden & & & & 4.8 & 0.005 & $1.4 ; 8.1$ & \\
\hline Bulgaria & & & & 5.2 & 0.004 & $1.6 ; 8.7$ & \\
\hline
\end{tabular}




\begin{tabular}{|c|c|c|c|c|c|c|c|}
\hline Relations with the family & & & & & & & 0.73 \\
\hline Boys & 3.4 & 0.04 & $0.2 ; 6.6$ & & & & \\
\hline Girls & 4.3 & 0.01 & $0.9 ; 7.6$ & & & & \\
\hline Sweden & & & & -1.8 & 0.28 & $-4.9 ; 1.4$ & \\
\hline Bulgaria & & & & -0.9 & 0.58 & $-4.3 ; 2.4$ & \\
\hline Relations with others & & & & & & & 0.51 \\
\hline Boys & 4.5 & 0.003 & $1.6 ; 7.5$ & & & & \\
\hline Girls & 3.1 & 0.049 & $0.02 ; 6.2$ & & & & \\
\hline Sweden & & & & 0.3 & 0.85 & $-2.7 ; 3.2$ & \\
\hline Bulgaria & & & & -1.1 & 0.47 & $-4.2 ; 2.0$ & \\
\hline
\end{tabular}

${ }^{\mathrm{a}} \beta$ denotes difference in score between Swedish and Bulgarian adolescents.

${ }^{\mathrm{b}} \beta$ denotes difference in score between boys and girls.

The comparison between the countries and between boys and girls in terms of global self-esteem, measured with the ITIA global-scale, showed that the Swedish boys had a 12.7 points higher mean score than the Bulgarian boys $(\mathrm{p}=0.02$ ) whereas the Swedish girls had a 5.0 points higher mean score than the Bulgarian girls on the ITIA global-scale. The difference between the girls, in contrast to the difference between the boys, was non-significant $(\mathrm{p}=0.36)$. No significant differences between the countries were seen in the sub-scales 'Physical characteristics', 'Talents and skills', and 'Psychological well-being' although a borderline difference was observed in the sub-scale 'Talents and skills' for boys. There were significant differences in the two relational self-esteem sub-scales, 'Relations with the family' and 'Relations with others', between the countries where both the Swedish girls and boys had higher scores than their Bulgarian counterparts.

The comparison between the sexes in the two respective countries showed that the Swedish boys had significantly higher scores than the Swedish girls on the ITIA global scale as well as on the two scales 'Physical characteristics', and 'Talents and skills'. For 'Psychological well-being', a significant sex difference was found in both Sweden and Bulgaria where 'Psychological well-being' had higher scores in boys than girls in both countries.

There was a significant interaction between country and sex on the sub-scale 'Talents and skills' where the differences between boys and girls went in different directions in the two countries. In Sweden, boys scored higher than girls, whereas in Bulgaria boys scored lower than girls.

We also made a sensitivity analysis with imputed values for the missing items, as described in the statistics section above, and found that the results were almost identical.

\section{Discussion}

\subsection{Main Findings}

There are several findings in this study worth mentioning. The Swedish adolescents reported a significantly higher global self-esteem than the Bulgarian adolescents and this overall country difference was explained by the significantly higher reported scores in the Swedish males compared to the Bulgarian males. No country difference was found between the adolescent females. Moreover, the overall country difference in self-esteem was mainly driven by the higher scores in the two relational sub-scales 'Relations with the family' and 'Relations with others' where the Swedish adolescents of both sexes had significantly higher scores in the two relational sub-scales compared with the Bulgarian adolescents. The Bulgarian adolescents reported less differences between the sexes, although both the Bulgarian and the Swedish males reported significantly higher scores than the Bulgarian and Swedish females, respectively, in one of the sub-scales, i.e., 'Psychological well-being'. The Swedish males reported significantly higher scores than the Swedish females also in the sub-scales 'Physical characteristics' and 'Talents and skills' in addition to the sub-scale 'Psychological well-being', resulting in a significant overall difference in self-esteem between the sexes in Sweden. These findings might indicate that both the higher global self-esteem in the Swedish adolescents, as well as the less obvious overall differences between the sexes in Bulgaria, could be of national essence and potentially explained by the differences in governance. The higher scores for males in the sub-scale 'Psychological well-being' in both Swedish and Bulgarian adolescents may, however, be explained by gender differences present in both types of governance. 


\subsection{Previous Research}

Very little research has previously been performed on personality traits in relation to dictatorships and, to our best knowledge, only one on self-esteem and personality development (Inkeles, 1958). The subjects in that study, published 60 years ago, were active Soviet defectors with 'disaffection' with the Soviet system, inferring a selection bias. The sample was studied with an interview and a battery of tests on psychometric characteristics, which have not been evaluated on reliability and validity. Levels of self-esteem were found to be 'rather high and secure', although without any definition of self-esteem or any methodological description on how it was assessed, apart from generic interviewing. The authors discussed the collective dependence in the collective and the great strains the mutual surveillance systems put on the relations as well as the haughtiness of the élite classes and the dissolving of old structures and the strong effects this seem to have on the 'trust-distrust' polarization. They found the trust vs. distrust polarization to be the overall dilemma in the Soviet citizen's relation to authorities. If this holds true, it may have a generalizing effect on other relations as well. They further theorized that the need for a group loyalty could change loyalty from that within a family towards other groups such as the Komsomol and that the official shaming strategy of the Soviet society also might have led to a general desensitization from shame, if not in moral failures. The authors concluded that the results remain conjectural as long as better studies can be conducted and the article could be seen as hypothesis-forming from qualitative data. Several years later, Kling et al found no articles from any Soviet-bloc country in their meta-analysis on self-esteem in 1999 (Kling et al., 1999).

\subsection{Relational Scales and Dictatorship}

Our findings that high scores in the relational scales, i.e. in the sub-scales 'Relations with the family' and 'Relations with others', explained the high overall global self-esteem score is supported by Harter, who reported that self-esteem in adolescents has been shown to be well correlated with perceived support from significant others, both peers and parents, with a range from .50 to .65 (Harter, 1993). One explanation as to why the self-esteem in relation to the family was better in Sweden than Bulgaria could be that in a dictatorship the state by itself acts as a new 'ideological family' (Moghaddam, 2013), in both words and deeds, and is relatively indifferent to the biological family in itself. This is well in-line with the early Soviet pedagogical theorists that wanted to relieve the children from the 'egoism of the family' and the 'influence of the parents' in order to stamp out a new kind of human, i.e., the 'Bolshevik of the right kind' (Kalling-Kant, 1948; Makarenko, 1979).

\subsubsection{Relations With Others and Mutual Surveillance}

The lower scores in Bulgarians than Swedes for the sub-scale 'Relations with others' could be seen as a conflict between the forming of self-esteem in the individual and the goal of the kollektiv that in the Soviet-bloc was a goal of production for the society, a superior, non-negotiable goal and defined well outside the interests of the individuals in the group. The goal was reached by constant watching and evaluation of people's colleagues in the unit, a mutual surveillance, described as 'the reliable bedrock' or 'cornerstone' of Soviet power (Kharkordin, 1999). By adding many different commissions with different tasks, consisting of different persons, and each with their own power of enforcing discipline, every pupil plays the role of both watcher as well as being watched and living in a constant threat, what Kharkordin refers to as 'the principle of horizontal discipline'. In the most democratic form of this power system everyone is in command for some little time and thus is a tyranny of oneself mediated by the kollektiv where one is both a suppressor and a subject of suppression (Kharkordin, 1999). The lower self-esteem in relation with others, mainly peers and teachers, could be theorized to be related to the system of mutual surveillance and a reluctance of discussing non-authorized viewpoints for the fear amongst people in the relation to their peers and due to potential repression from the autocratic state.

\subsubsection{Relations With Others and Secrecy}

The finding of a lower score in the sub-scale 'Relations with others' in the Bulgarians could also be related to the secrecy in the dictatorships as secrecy is reported to increase in autocracies (Moghaddam, 2013). This is in order to safeguard the in-groups, either the political elite or the secret opposition. As freedom is limited, rumours tend to replace open information transfer, since the latter is known to be censored. This leads to difficulties in distinguishing what to believe and possibly to an increased relativity in terms of truth and source criticism. The dictator and his clique leave no room for alternative interpretation than the views of the supreme leader as a critical discourse would threaten the dictator (Moghaddam, 2013). This secrecy and the strong creation of in- and out-groups could be another reason why the result of the 'Relations with others' scale is higher in the democracy Sweden. In the adolescent, a growing understanding of the surrounding society, not just the in-group of peers and family, combined with the lack of freedom and state of repression in a dictatorship should thus theoretically lead to a sensation of lack of control and thus both a lacking self-esteem and a lacking sense of coherence 
(Antonovsky, 1987). Recent research has confirmed the positive association between sense of coherence and self-esteem (Moksnes \& Lazarewicz, 2016).

\subsubsection{Relations With Others and Perception of Support}

The perception of support, rather than the actual support, is highly important for high self-esteem. This perception does not need to be consistent with how others de facto value them, according to Harter (Harter, 1993). Harter also stated that the conditionality of the perceived level of social support, i.e., the degree to which the support is perceived to be related to a condition put on the individual, e.g., achieving a good academic result, is inversely correlated to self-esteem. The overall goal of production in the communistic dictatorship could be seen as a condition for the social support of the individual and thus as something that diminishes relational self-esteem and, in continuation, in global self-esteem. It is therefore possible that the conditionality of the perceived level of social support is more pronounced in a communistic dictatorship than in a Western democracy.

\subsubsection{Relations With Others and the Demand-Control-Support Model}

Apart from the social stressors of fear of repression from peers and the state of mind it may lead to, another social stressor that could correlate to the lower relational self-esteem in the Bulgarian adolescents is described in the demand-control-support model by Karasek and Theorell (Karasek \& Theorell, 1990). The model stipulates that the worst stress scenario is a situation where the psychological demands of a job are high and the person's decision latitude in the task is low. Lack of decision latitude is described as a constraint to the freedom to take action in a stressful situation or the combination of a breadth of skills and social authority over making decisions. They also note that the more adverse effects of stress, or strain symptoms, such as depression, loss of self-esteem and physical illness are more strongly associated with low decision latitude and not only the stressors and the resulting stress in itself (Karasek \& Theorell, 1990). This leads us to one approach that could be used for interpreting the differences between Sweden and Bulgaria as the shaming and punishment system of Makarenko is a good example of a social stressor with the insatiable demand of ever-higher production in combination with the communistic pedagogical system with pre-fabricated truths and goals that are non-negotiable in terms of decision latitude. A stressor is defined as the causative factor retaining stress as the resulting condition and social stress is well-known to cause objectively measurable changes in stress hormone production (Selye, 1976). This also infers that several of the above-mentioned mechanisms are potent stressors, i.e. the constant stress of being part of the mutual surveillance and lack of sense of coherence with the strong in- and out-groups because of the secrecy in the dictatorship.

\subsubsection{Relations With Others and Propaganda}

Another strong stressor that might be connected to the lower relational self-esteem in the Bulgarian adolescents might be the association between the normative correct views on subjects delivered by the propaganda channels of the Soviet-bloc and the possible resulting feeling of being an unwanted element and the following evasive manoeuvres. We have found no data on adolescents, but as much as half of the adult population in the Soviet-bloc was reported to have listened regularly to West-European radio. Bulgaria was one of the five Soviet-bloc countries that were targeted by Radio Free Europe, a propaganda project aimed to win hearts and minds of the peoples of the Soviet-bloc by promoting freedom and democracy through palatable programmes made for, and sometimes by (through smuggled messages), the people from the Soviet-bloc (Risso, 2013). The $\mathrm{BBC}$ had a programme called 'Letters without signatures' where anyone daring could mail to a post box in Berlin from where the letters were forwarded to the BBC and read during the programme. A 17-year-old East German, wrote 'I grew up in this country (...) but don't think it's fun, always having to say the opposite of what you think' (d'Arcy, 2017). Hiding and suppressing your feelings in fear of being labelled enemy of the state by anyone from the ever-present mutual surveillance would likely have been a huge stressor. The role of hiding one's inner from the world creates difficulties in assessing both other's perceptions of oneself as well as recognizing one's own strengths (Fink, 2010), which both have been shown to lead to lower self-esteem (Harter, 1993). Sometimes unwanted facts about oneself are separated from the persona through dissociation, which could have been a suitable way for survival but is another strong stressor both in terms of hiding but also in the constantly raised vigilance for detecting something threatening to discover the hidden flaws (Fink, 2010).

\subsection{Differences Between the Sexes}

The Bulgarian adolescents reported less difference in self-esteem between the sexes than the Swedish adolescents where the Swedish males reported significantly higher scores than the Swedish females in the sub-scales 'Physical characteristics' and 'Talents and skills' in addition to the global self-esteem. Urie Bronfenbrenner is one of the few researchers that studied child and adolescent development across the iron 
curtain and made comparisons between the USA and the Soviet Union although not in terms of self-esteem per se (Bronfenbrenner, 1962). He writes in his book 'Two Worlds of Childhood' that it is mainly girls that play the key roles in the collective discipline acting both as leaders of the collectives and therefore also as judges in the cases where a punishment is to be dealt out and administered (Bronfenbrenner, 1976). This could be one reason to the minor difference in self-esteem between the sexes in Bulgaria; the almost exclusively female exertion of power in the collective is an expression of power and likely to decrease the feeling of poor self-esteem. A previous study on self-esteem in different countries found that self-esteem is positively correlated to Power Distance indicating that a person that is far from the power or less influential has a lower self-esteem (Schmitt \& Allik, 2005).

The lesser difference between the sexes in Bulgaria might be a result of the emancipation, which was an important socialist dogma in Bulgaria. In the Soviet-bloc, many women were represented in the parliament as well as in relatively high-profile fields such as medicine (Kruks, 1989). Makarenko highly advocated mixed-sex education in order to early form the emancipated communistic woman (Makarenko, 1979). In dictatorships, women are often idealized in being self-sacrificing, warm and with a focus on high fertility (Moghaddam, 2013; Molyneux, 1981). The reproductive function of the women was viewed as of major interest for the state and socialist iconography normally represented women as working mothers more than just workers (Molyneux, 1981; Petrova, 1994). In the Soviet-bloc almost no advertisements were allowed and a common and strong image of women were the mural paintings of the ideal and strong communist woman as a farmer, engineer or soldier (Kruks, 1989) whereas most images of women on the streets in Western democracies, including Sweden, were advertisements, where many of the women were objectified by their looks rather than for their strong contribution to society. This could have had a negative impact on the self-esteem of the Swedish girls in the study; something that is well in-line with Harter's finding of the conditionality of the perceived level of social support (Harter, 1993).

\subsection{Psychological Well-Being}

The female adolescents in both countries in our study reported lower scores on the sub-scale 'Psychological well-being' than the male adolescents. A lower psychological well-being in females than males is well-known from earlier findings in Sweden (Bremberg, 2006; Folkhälsomyndigheten, 2010; Hagquist \& Forsberg, 2007; Petersen, 2007; Thorsén, Antonson, Sundquist, \& Sundquist, 2016), although, to our best knowledge, it has never previously been shown in the Soviet-bloc. The lower self-esteem in females in the sub-scale 'psychological well-being' in both Sweden and Bulgaria could possibly have a biological explanation, as we see no difference between the two countries. It has been shown that biological changes during puberty are closely linked to depression, as rising sex-hormone levels in adolescent girls potentiate the risk of depression through mechanisms that are unrelated to the psychosocial effects of morphological changes in girls' bodies (Angold, Costello, Erkanli, \& Worthman, 1999).

\subsection{Self-Esteem and Curriculum}

King reports that development of self-esteem and self-concept is a crucial concern for health education in schools as the two factors are important for healthy behaviour as well as academic achievement, quality in social relations, and adoption of coping skills (King, 1997). The importance of the curriculum in how to develop self-esteem is crucial also according to Beane, who suggests that the best way of integrating the development of self-esteem by the means of the curriculum is by devoting more attention to syncretize the many sources of self-images a child must process (Beane, 1982). How health education in schools should be performed is normally governed by the curriculum. The curriculum gives the rules of how the governing bodies wanted the school to work in order to achieve the goal of forming good citizens. We do not know to which extent they were followed in the two nations but not all of a teenager's behaviour is formed in school. The family and the surrounding society are certainly also important when it comes to forming the personality and the level of self-esteem. One way of expressing oneself as a teenager, valid on both sides of the Iron Curtain, was through clothing and looks. In the Soviet Union, a small change of looks would be easily visible among the uniformed pupils. A movement called styliagi was sternly repressed by the government. This individualization was also deemed to be harder to perform by women than men in the Soviet-bloc, despite the emancipation (Kharkordin, 1999). In Sweden, the expression of oneself through a sub-cultural dress and style was seen as normal but although some of the expressions might have been frowned upon by the authorities, no repression would have followed.

\subsection{Other Cultural Differences}

There were other cultural differences between the countries than the governance and the curricula formed by the 
two systems. Bulgaria is a country belonging to the more southern sphere of countries in Europe whereas Sweden is a North-European country. In addition, Sweden has never been occupied and hasn't been at war since 1814, whereas Bulgaria is a country that has been formed by centuries of occupation as the country was occupied by the Ottoman Empire from 1396 until 1878 when it was liberated by help from Russia after the peace treaty in the Russo-Turkish war 1877-1878. The country has also suffered from several other wars after that. Both countries share a Christian faith although the Swedish State church was Lutheran and the Bulgarian Orthodox Church is the oldest Slavic Orthodox church. The Christians in Bulgaria were treated as an inferior class of people during the Ottoman occupation. The countries were relatively secular at the time of the present study but the differences in creed have formed traditions and ethics that live on in newer cultural settings. How these differences in culture and creed might have influenced the results in self-esteem is unclear and the two variables, governance and culture, could have been mutually confounded.

\subsection{Limitations}

Although there are many similarities between the two countries, (see paragraph 2.1. Study population), there are also many differences in, e.g., culture (see paragraph 4.7 Other cultural differences). This makes it difficult to conclude that governance is the cause behind the differences in self-esteem rather than a multitude of uncontrolled variables related to the cultural differences between countries. Other limitations that hamper the possibility to draw conclusions about causality are the cross-sectional nature of our study and the relatively small sample size.

In a collective society, individuals are more concerned with fitting in than of positive self-evaluations, i.e. the social relationships are more important than the individual's accomplishments. This means that self-critique is more goal-achieving than positive self-evaluation with respect to collectivism, which may make self-esteem questionnaires like the 'I Think I Am-scale' or the Rosenberg Self-Esteem scale less prone to be comparable on a cross-cultural level. This is partly due to acquiescence bias, the tendency to agree positively to all items. The choice of scales constructed with both positive and negative statements in its items, such as the ITIA-scale, has been discussed to nullify the effect of collectivism-individualism in self-esteem (Schmitt \& Allik, 2005). This would seem to be important when comparing Sweden with Bulgaria as the Bulgarians would be more prone to answer in-line with someone else's views according to both form of governance and the socialistically formed curriculum. Children up to the $10^{\text {th }}$ grade have been shown to have a problem, decreasing with age, answering negative items, sometimes referred to as the negative item bias. This has been shown to vary with literacy and language skill such as if you answer the questionnaire in your mother tongue (Schmitt \& Allik, 2005). Since both groups answered the test in their native tongue and the primary school completion rates in the two countries were similar (The World Bank, 2016), and thus most certainly the literacy, we believe the advantages of the acquiescence bias should outweigh the limitations of the negative item bias in this study.

It could be argued that the self-esteem definition of the ITIA-scale infringes on self-concept and also encompasses a sub-scale of psychological well-being normally excluded from the definition of self-esteem. The scale has, however, been shown to have a good validity in comparison with psychological interviews (Birgerstam, 2013) and has furthermore been shown to be of good clinical value indicated by being the second most used questionnaire in Sweden's largest health care provider, the Stockholm County Council (Dunerfeldt, 2010).The terms self-esteem and self-concept have a multitude of different definitions and are often used interchangeably, although they represent two discrete dimensions (King, 1997). Both self-esteem and self-concept are very important for the development of self-perception (Beane, 1982).

The sample of only one city in both countries could give rise to a geographical selection bias, as could the choice of only studying populations in cities. The suitability of the Bulgarian population as representative of the country during the time of the data collection is hard to deduct today, but since no demographical data was possible to attain for the researchers and the approximation was deemed justified also by independent researchers in Bulgaria, the chosen population could be deemed reasonably generalizable for Bulgaria in 1989. Comparing the population from the capital in one country to a medium sized city in the other could also be a bias but this selection was justified on the basis of migration patterns as Stockholm was growing steadily whereas Sofia had an internal migratory block and during the Communist regime migration was a choice underlined by political reasons, not a choice by an individual (Beleva, 2001).

Use of more than one scale could have given a better understanding of the situation and could have illuminated other aspects of the personality development than the perception of the self. The age-group gives just a small representation of the society, although adolescents are more plastic than adults and hence could be more likely to show a difference between societies that could be more diverse in an older group. 
There is a lack of information about Bulgarian drop-outs since no data could be attained due to the local regulations but we have no reason to believe that there were any significant differences in drop-out rates since no epidemic was reported and the attendance rate in Bulgarian schools were reported to be very high due to social control.

\subsection{Strengths}

The key strength of this study lies in its unique data from both sides of the Iron curtain that outweighs its limitations. All of the data were collected by a single bilingual physician, specialized in child and adolescent psychiatry, in a familiar classroom situation for the children. Data from Bulgaria were collected before the fall of the Berlin wall in November 1989 and the last collected Swedish data were acquired only one and half years later in a stable democratic society, i.e. a time difference that should not have had an effect upon the results. The survey was made with a reliable, well-validated scale previously used in comparisons between countries and with translations to other languages. The Bulgarian version of the scale was made in a thorough process of translation and re-translation performed by bilingual physicians. The choice of schools in relation to socioeconomic levels was designed in an attempt to nullify social differences within the countries and thus to get a sample that could be deemed representative for the country. The study of dictatorships and its population's personality development is very hard to acquire since secrecy is a well-known trait of the dictatorship elite (Moghaddam, 2013). Getting an opportunity like this to study such a topic is thus very rarely encountered in a world where dictatorships are many, and the debate on how a nation should be governed is too seldom discussed on a scientific basis.

\section{Conclusions}

Despite the limitations, our study is based on the only known existing data from before the fall of the Berlin wall comparing self-esteem in a country belonging to the autocratic Soviet-bloc and a West-European democracy, data that are no longer possible to obtain. In general, the possibility to perform research in dictatorships is very hard to achieve. The democracy Sweden formed adolescents with significantly higher self-esteem than the communistic dictatorship Bulgaria, which might have been caused by social stressors leading to a 'Dictatorship damage' consisting of a lower self-esteem. The communistic dictatorship had, however, less difference in self-esteem between the sexes than Sweden, something that possibly could be attributed to the idealization of the strong emancipated woman, which was a social icon in the Soviet-bloc.

\section{Supplementary information}

\subsection{List of Abbreviations}

\section{ITIA - 'I Think I Am' scale.}

\subsection{Declarations}

\subsubsection{Ethics approval and consent to participate}

We acquired the legally required permission for the study and publication from the local ethics committee (Etikprövningsnämnden) in Lund, Sweden (reference No. LU 60-1989). The necessary authorization and ethical permission for the Bulgarian part of the study was acquired from the Bulgarian Academy of Science.

\subsubsection{Consent for Publication}

Consent forms were not used at the time of the data-collection and were not required by the local ethics committee or authorities. All data were collected anonymously.

\subsubsection{Availability of Data and Material}

The datasets used and analysed during the current study are available from the corresponding author on reasonable request.

\subsubsection{Competing Interests}

The authors declare that they have no conflict of interest.

\subsection{Acknowledgements}

We would like to thank Patrick Reilly for correcting the language. We are also grateful to professor H. Hristozov from the clinic of Children and Adolescent Psychiatry, Medical Academy, Sofia, who helped us with acquiring the permissions necessary from the Bulgarian authorities. The aid from professor M. Atchovka from the same clinic was essential for the translation of the test as well as for evaluating the choice of population. Furthermore, we would like to thank the bilingual Dr. Stella Boiadjieva who did an important task in the translation of the "I 
think I am"-scale back from Bulgarian to Swedish. We would also like to thank the former headmistress Marianne Antonson for invaluable information on the Swedish curriculum and educational legislature in the 80's and the teacher Leif Bruce who taught the first author the values of democracy in accordance with the curriculum in the early 90 's so that he remembered it 25 years later.

\subsection{Authors' information}

N/A.

\section{References}

Angold, A., Costello, E. J., Erkanli, A., \& Worthman, C. M. (1999). Pubertal changes in hormone levels and depression in girls. Psychol Med, 29(5), 1043-1053. https://doi.org/10.1017/S0033291799008946

Antonovsky, A. (1987). Unraveling the mystery of health: how people manage stress and stay well (1st ed.). San Francisco, California: Jossey-Bass.

Aronson, E., \& Aronson, J. (2012). The social animal (11th ed.). New York: Worth Publishers.

Arvidsson, T. (1998). Självvärdering och kreativitet - En jämförande studie av gatubarn, barnhemsbarn och skolbarn i Mexico City. Stockholm University, Stockholm.

Beane, J. (1982). Self-Concept and Self-Esteem as Curriculum Issues. Educational Leadership, (April), 504-506.

Beleva, I. K. M. (2001). Bulgaria - Country Study on International Skilled Migration (December). Retrieved from https://mpra.ub.uni-muenchen.de/47564/1/MPRA_paper_47564.pdf

Birgerstam, P. (2013). Jag tycker jag är - 2 : Bedömning av barns och ungdomars självkänsla (3rd ed.). Stockholm: Hogrefe.

Bos, A. E. R., Huijding, J., Muris, P., Vogel, L. R. R., \& Biesheuvel, J. (2010). Global, contingent and implicit self-esteem and psychopathological symptoms in adolescents. Personality and Individual Differences, 48, 311-316. https://doi.org/10.1016/j.paid.2009.10.025

Bremberg, S. (2006). Ungdomar, stress och psykisk ohälsa. Analyser och förslag till åtgärder (pp. s.15): Statistiska Centralbyrån.

Bronfenbrenner, U. (1962). The Role of Age, Sex, Class, And Culture In Studies of Moral Development. Religious Education, 57(sup4), 3-17. https://doi.org/10.1080/003440862057S402

Bronfenbrenner, U. (1976). Två barndomsvärldar. Lund, Sweden: Wahlström \& Widstrand.

Churchill, W. (1946). The Sinews of Peace. Retrieved from https://www.winstonchurchill.org/resources/speeches/1946-1963-elder-statesman/the-sinews-of-peace/

Collier, D., \& Levitsky, S. (1997). Democracy with Adjectives: Conceptual Innovation in Comparative Research. World Politics, 49(3), 430-451.

d'Arcy, A. (2017). The German schoolboy jailed for writing to the BBC. BBC News Magazine. Retrieved from http://www.bbc.com/news/magazine-41283012

Dunerfeldt, M. E., Anna, \& Söderström, B. (2010). Bedömningsinstrument inom BUPi Stockholm. Kållered: Intellecta Infolog Retrieved from http://www.bup.se/globalassets/dokument/om-bup/publicerat/aktuella_rapporter/rapport_bedomningsinstru ment_inom_bup_i_stockholm.pdf

Fink, G. (2010). Stress Consequences: Mental, Neuropsychological and Socioeconomic. Elsevier Science.

Folkhälsomyndigheten. (2010). Folkhälsopolitisk rapport 2010: framtidens folkhälsa - allas ansvar. Stockholm: Statens folkhälsoinstitut, 2010.

Hagquist, C., \& Forsberg, E. (2007). Ung i Värmland 1988-2005: en undersökning bland niondeklassare / Curt Hagquist, Erik Forsberg. Karlstad: Fakulteten för samhälls- och livsvetenskaper, Folkhälsovetenskap, Karlstads universitet, 2007.

Harter, S. (1993). Self-Esteem - The Puzzle of Low Self-Regard. In R. F. Baumeister (Ed.). New York: Plenum Press.

Hogstrom, J. (2013). Does the Choice of Democracy Measure Matter? Comparisons between the Two Leading Democracy Indices, Freedom House and Polity IV. Government And Opposition, 48(2), 201-221. https://doi.org/10.1017/gov.2012.10 
Inkeles, A. H. E., \& Beier, H. (1958). Modal Personality and Adjustment to the Soviet Socio-Political System. Human Relations, 11(1), 3-22. https://doi.org/10.1177/001872675801100101

Kalling-Kant, L. (1948). Makarenko och hans metod. Lovisa, Finland: Söderström \& Co. Förlagsaktiebolag.

Karasek, R. \& Theorell, T. (1990). Healthy Work: stress, productivity, and the reconstruction of the working life. New York, USA: Basic Books.

Kharkordin, O. (1999). The Collective and the Individual in Russia. University of California Press.

Kimber, R. (1989). On Democracy. Scandinavian Political Studies, 12(3), 199-219. https://doi.org/10.1111/j.1467-9477.1989.tb00090.x

King, K. (1997). Self-Concept and Self-Esteem: A Clarification of Terms. Journal of School Health, 6(2), 68-70. https://doi.org/10.1111/j.1746-1561.1997.tb06303.x

Kling, K. C., Hyde, J. S., Showers, C. J., \& Buswell, B. N. (1999). Gender differences in self-esteem: A meta-analysis. Psychological Bulletin, 125(4), 470. https://doi.org/10.1037/0033-2909.125.4.470

Kruks, S. R., Rayna, Y., \& Marilyn, B. (1989). Promissory notes: women in the transition to socialism. New York: Monthly Review Press.

Makarenko, A. (1979). Vägen till Livet (Pedagogiskt Poem). Moscow, USSR: Progress.

Marshall, M., Gurr, T., \& Jaggers, K. (2018). POLITY IV PROJECT Political Regime Characteristics and Transitions, 1800-2017 Dataset Users' Manual. Retrieved from http://www.systemicpeace.org/inscr/p4manualv2017.pdf

Moghaddam, F. M. (2013). The psychology of dictatorship. American Psychological Association.

Moksnes, U., \& Lazarewicz, M. (2016). The association between self-esteem and sense of coherence in adolescents aged 13-18years-The role of sex and age differences. Personality and Individual Differences, 90(Feb), 150-154. https://doi.org/10.1016/j.paid.2015.10.049

Molyneux, M. (1981). Women's emancipation under socialism: A model for the Third World? World Development, 9(9-10), 1019-1037. https://doi.org/10.1016/0305-750X(81)90057-7

Ouvinen-Birgerstam, P. (1984). Identitetsutveckling hos barn. Lund: Studentlitteratur.

Ouvinen-Birgerstam, P. (1985). Jag tycker jag är / Pirjo Ouvinen-Birgerstam: Stockholm : Psykologiförl.

Petersen, S. (2007). Barns och ungdomars psykiska hälsa i Sverige. En systematisk litteraturöversikt med tonvikt på förändringar över tid.: Hälsoutskottet.

Petrova, D. (1994). Women in East and Central Europe: What can women do to change the totalitarian cultural $\begin{array}{lllll}\text { context? Women's } & \text { Studies International }\end{array}$ https://doi.org/10.1016/0277-5395(94)90033-7

Risso, L. (2013). Radio Wars: Broadcasting in the Cold War. Cold War History, 13(2), 145-152. https://doi.org/10.1080/14682745.2012.757134

Schmitt, D. P., \& Allik, J. (2005). Simultaneous Administration of the Rosenberg Self-Esteem Scale in 53 Nations: Exploring the Universal and Culture-Specific Features of Global Self-Esteem. Journal of Personality and Social Psychology, 89(4), 623-642. https://doi.org/10.1037/0022-3514.89.4.623

Selye, H. (1976). The stress of Life (Revised Paperback Edition, 1978 ed.). New York: McGraw-Hill Companies, Inc.

Skolöverstyrelsen. (1980). Lgr 80. Mål och riktlinjer för grundskolan. (L. Tryck Ed.). Stockholm, Sweden: Utbildningsförlaget.

Socialist Party of Bulgaria. (1987). Колектив

Формиране и възпитание на личността. Sofia, Bulgaria: Партиздат.

Storm, L. (2008). An Elemental Definition of Democracy and its Advantages for Comparing Political Regime Types. Democratization, 15, 215-229. doi:https://doi.org/10.1080/13510340701846301

The World Bank. (2016). World Development Indicators; Primary completion rate, total. Retrieved from http://databank.worldbank.org/data/reports.aspx?source=2\&series=SE.PRM.CMPT.ZS\&country=

Thorsén, F., Antonson, C., Sundquist, J., \& Sundquist, K. (2016). Perceived Stress and Psychiatric Symptoms in Swedish Adolescents. Journal of Educational \& Developmental Psychology, 6(2), 183-194. 
doi:http://dx.doi.org/10.5539/jedp.v6n2p183

United Nations Secretariat. (2012). World Population Prospects: The 2012 Revision. Retrieved from http://esa.un.org/wpp/unpp/panel_population.htm

\section{Appendix A}

Boxplot of the 'I think I Am'-scale (ITIA) global divided by country with the extreme outlier represented by the dot

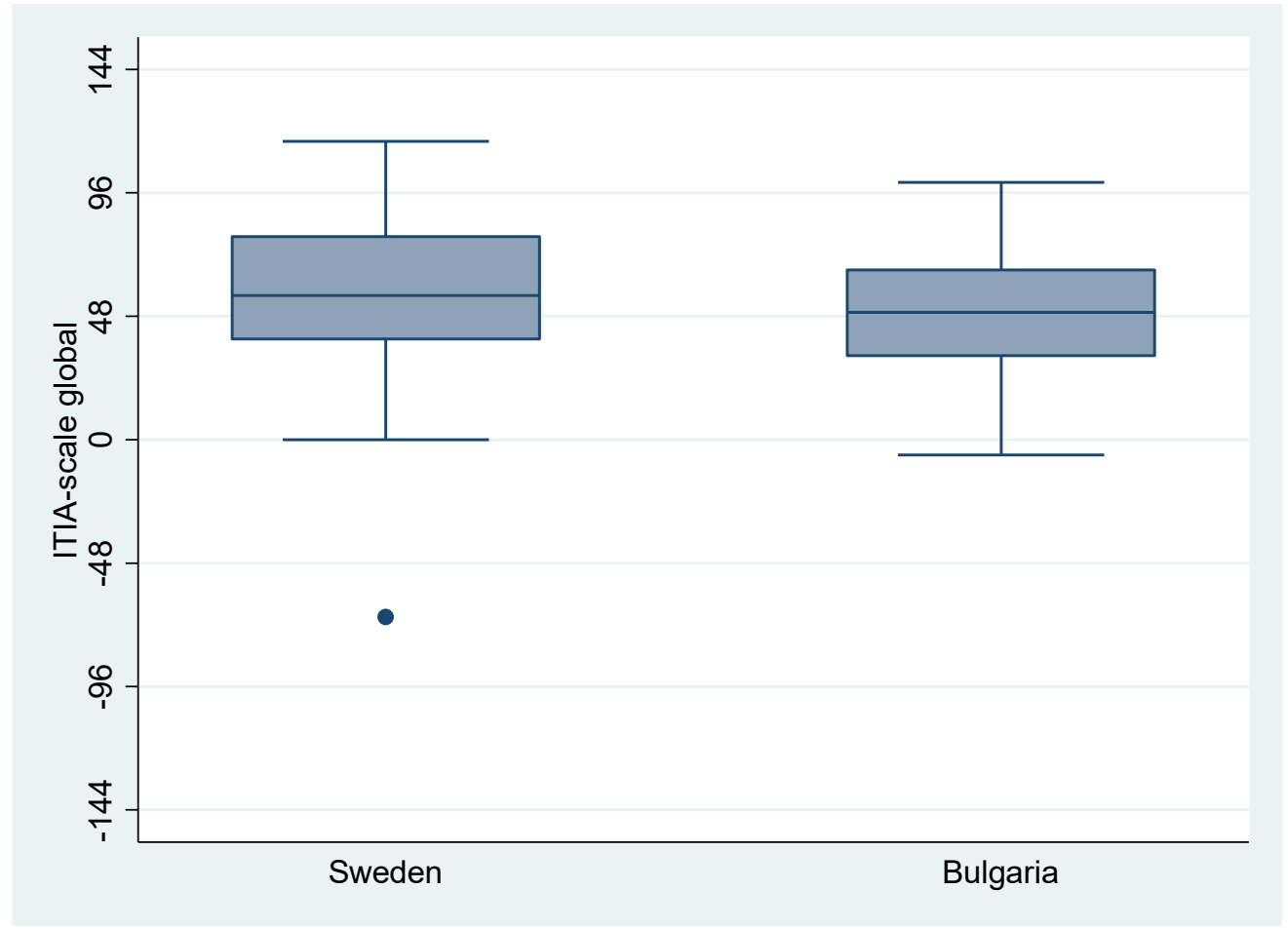

\section{Copyrights}

Copyright for this article is retained by the author(s), with first publication rights granted to the journal.

This is an open-access article distributed under the terms and conditions of the Creative Commons Attribution license (http://creativecommons.org/licenses/by/4.0/). 